\title{
KONTRIBUSI WANITA DALAM AKTIVITAS EKONOMI DAN RUMAH TANGGA KABUPATEN MALANG
}

\author{
Dwi Eko Waluyo \\ Pascasarjana Fakultas Ekonomi Universitas Negeri Surakarta \\ E-mail:dewaumm@yahoo.com \\ Uci Yuliati \\ Fakultas Ekonomi dan Bisnis Univesitas Muhammadiyah Malang
}

\begin{abstract}
This study was conducted to discover the women contribution on the dynamics of village economic activities. It was a very interesting topic to discuss since most of women in the village have low educational background and always directed to be workers. The respondents of this project were 51 housemaids who were selected by employing purposive sampling technique. Subsequently, the data which consisted of variables in the form of individual characteristics, earnings, and working hours were analyzed using cross-tabulation. The results showed that the majority of women workers' education is elementary school (47.1\%), junior high school (37.3\%), senior high school (7.8\%) and they were mostly less than 45 years old. In conclusion, women's income had contributed well to meet the expectations of family economy with average wage was 350,000 rupiah per month for 8 work hours per day.
\end{abstract}

Keywords: Housemaid, Iincome, Economic contribution

\begin{abstract}
Abstrak
Tujuan penelitian ini adalah untuk mengetahui kontribusi perempuan dalam kegiatan ekonomi. Ini menarik karena perempuan di desa itu pendidikan masih rendah dan dilakukan ke lapangan kerja. Responden sebanyak 51 wanita hamba yang diambil dengan menggunakan purposive sampling. Data analisis adalah tabulasi silang dan variabel terdiri individu karakteristik, pendapatan dan pekerjaan jam. Hasil penelitian menunjukkan bahwa pendidikan perempuan adalah sekolah dasar $(47,1 \%)$, SMP (37,3\%), sekolah menengah atas (7,8\%). Kebanyakan wanita yang berusia di bawah 45 tahun. Pendapatan perempuan telah memberikan kontribusi ekspektasi ekonomi keluarga mereka. Rata-rata penghasilan mereka adalah 350.000 rupiah selama 8 jam per hari.
\end{abstract}

Kata Kunci: Pembantu Rumah Tangga, Pendapatan, Kontribusi Ekonomi

Saat ini, di Indonesia terdapat 2.5 juta orang yang menjadi pekerja rumah tangga (PRT), berdasarkan jumlah tersebut ternyata $90 \%$ merupakan pekerja rumahtangga wanita. Faktor yang paling mendorong tingginya jumlah wanita yang bekerja sebagai pembantu rumah tangga adalah kemiskinan dan krisis ekonomi, keingingan untuk mencari pengalaman hidup di kota serta menghindari perkawinan usia dini dan ajakan saudara atau kerabat yang 
terlebih dahulu bekerja sebagai pekerja rumah tangga.

Keterlibatan wanita bekerja di luar rumahtangga sebenarnya merupakan gejala yang sudah biasa, terutama bagi masyarakat lapisan bawah. Berdasarkan pada kenyataan dari tahun ke tahun jumlah wanita yang memasuki pasaran kerja semakin meningkat sejalan dengan perkembangan masyarakat yang memberi kesempatan luas pada wanita. Salah satu kenyataan sumbangan wanita dalam pembangunan adalah partisipasi wanita sebagai pekerja dalamberbagai kehidupan masyarakat. Konsekuensi dari partisipasi tersebut nampak dari berbagai masalah yang dihadapi, terutama jika melihat "peran ganda" dari wanita dalam rumah tangga dan masyarakat secara umum. Wanita selain sebagai ibu yang melahirkan anak juga sebagai pencari kerja guna memperoleh pendapatan.

Pembantu rumahtangga(PRT) juga melakukan reproduksi sosial dan berjasa dalam menjaga keharmonisan keluarga di kotakota besar di Indonesia. Suami dan istri yang bekerja diranah publik, rata-rata membayar jasa PRT untuk melakukan kerja-kerja kerumahtanggaan. Meskipun pembantu rumah tangga memiliki sederet peran signifikan baik baginegara, keluarga dan majikan, namun nasib mereka hampir tidak pernah berubah dari masa ke masa. Kompleksnya masalah yang dialami para pembantu rumah tangga di antaranya karena pekerjaan ini "tersembunyi ( $h i$ dden), tidak terlihat (invisible) dan terabaikan (ignored)", sehingga banyak kasus kekerasan dan pelanggaran hak sebagai warganegara, pekerja, wanita, dan anak tidak dapat dideteksi secara cepat.

Implikasi dari pembicaraan tentang wanita memiliki banyak makna antara lain bahwa wanita identik dengan wilayah domestik terasa dalam bidang pendidikan. Banyak wa- nita Indonesia, terutama di daerah pedesaan, tidak menempuhjenjang pendidikan yang lebih tinggi. Seringkali mereka disekolahkan oleh orang tua mereka hanya sampai jenjang pendidikan menengah. Jenjang pendidikan yang rendah berakibat pada minimnya lowongan kerja yang mereka masuki. Oleh karena itu menjadi pekerja pembantu rumah tangga merupakan pilihan yang paling tersedia bagi mereka.

Masalah pekerjaan sebagai pembantu rumah tangga tidak hanya berhubungan dengan representasi wanita dan tingkat pendidikan yang rendah, tapi juga berkenaan dengan hak-haknya sebagai seorang pekerja. Rendahnya tingkat pendidikan juga memberi sumbangan pada ketidakpahaman PRT dengan hak-haknya sebagai pekerja. Dengan demikian dapat berakibat pada rendahnya pendapatan yang diterima, jamkerja yang terlalu lama, pekerjaan yang tidak sesuai dengan keahliannya serta perlakuan menyimpang lainnya. Hal itu tidak disadaripara pembantu rumah tangga.

Kecamatan Dau merupakan daerah perbatasan antara kota dan kabupaten Malang serta merupakan daerah perbatasan antara kota Batu dan kabupaten Malang. Perluasan kota Malang menjadi dampak terjadinya perubahan kondisi sosial ekonomi masyarakat Kecamatan Dau khususnya yang terjadi dan beberapa desa yang letaknya di pinggiran kota Malang. Perubahan kondisi sosial ekonomi masyarakat ditunjukkan oleh adanya perubahan kondisi wilayah yang ditandai oleh semakin menyempitnya lahan pertanian dan semakin luasnya pembangunan sektor perumahan, yang juga akan berdampak pada penambahan jumlah penduduk baru (masyarakat pendatang) yang menetap. Kondisi inilah yang menjadikan terbukanya lapangan kerja di sektor jasa pembantu ru- 
mah tangga, sehingga berdampak pada banyaknya kaum wanita desa (ibu rumah tangga) yang berupaya untuk memperbaiki tingkat kehidupan ekonomi mereka melalui bekerja sebagai pekerja pembantu rumah tangga (PRT). Alokasi kebutuhan waktu antara rumah tangga dengan kegiatan di luar mencari nafkah sebagai PRT mempengaruhi pendapatan yang diterima serta sumbangannya pada ekonomi rumah tangga. Bhatty (1987) mengatakan bahwa suatu rumah tangga bertujuan memaksimalkan kesejahteraan keluarga dengan cara mengalokasikan waktu untuk bekerja mencari nafkah dan pekerjaan rumah tangga. Masuknya wanita dalam pasaran kerja di sektor informal/jasa (khususnya tenaga kerja pembantu rumah tangga) akan membawa konsekuensi dalam kehidupan rumah tangganya. Pekerjaandiluarrumahdi sektor ini akan mengurangi alokasi waktu dan tenaga yang bisa dicurahkan untuk pekerjaan sebagai ibu rumah tangga. Dengan demikian dapat digambarkan tentang bagaimana wanita membagi waktu antara pekerjaan dan rumah tangga (khususnya pekerja wanita pramuwisma) di dalam kehidupan rumah tangganya.

Pekerjaan diluar rumah di sektor ini akan mengurangi alokasi waktu dan tenaga yang bisa dicurahkan untuk pekerjaan sebagai ibu rumah tangga. Dengan demikian dapat digambarkan tentang bagaimana wanita membagi waktu antara pekerjaan dan rumah tangga (khususnya pekerja wanita pramuwisma) di dalam kehidupan rumah tangganya. Kondisi inilah yang menjadi daya tarik peneliti untuk mengkaji tentang seberapa besar kontribusi wanita pekerja pembantu rumah tangga dalam aktivitas ekonomi dan rumah tangga khususnya di kecamatan Dau kabupaten Malang dengan menetapkan beberapa permasalahan antara lain: (a) Bagaimana karakter- istik wanita (ibu rumah tangga) yang bekerja sebagai pembantu rumah tangga di kecamatan dau kabupaten malang. (b) Faktorfaktor apakah yang menjadi alasan wanita (ibu rumah tangga) memilih bekerja sebagai pembantu rumah tangga (pramuwisma). (c) Bagaimana alokasi waktu wanita (ibu rumah tangga) pekerja pembantu rumah tanggga, antara pekerjaan sebagai pembantu rumah tangga dengan peran sebagai ibu rumah tangga. (d) Seberapa besar kontribusi pendapatan wanita (ibu rumah tangga) yang bekerja sebagai pembantu rumah tangga terhadap pendapatan keluarga.

\section{Metode Penelitian}

Penelitian ini dilakukan di daerah kecamatan Dau Kabupaten Malang, dengan alasan karena daerah Dau merupakan wilayah yang berbatasan dengan Malang dan Batu. Sebagai daerah pinggiran kota yang banyak mengalami perubahan seiring dengan pertumbuhan perguruan tinggi dan banyaknya masyarakat pendatang terutama mahasiswa. Populasi penelitian ini adalah seluruh pekerja wanita yang bekerja di bidang jasa pembantu rumah tangga (pramuwisma) yang berada di kecamatan Dau Kabupaten Malang. Metode pengambilan sampeladalah dengan metode "Purposive Sampling”, di mana tujuan digunakan metode ini untuk menentukan besarnya sampel (responden) di wilayah kecamatan Dau adalah banyaknya wanita yang bekerja sebagai pembantu rumah tangga dengan status sebagai ibu rumah tangga dan sudah menikah.

Pengumpulan data dengan menggunakan wawancara terstruktur dengan instrument daftar pertanyaan. Variabel yang dianalisis meliputi karakteristik individu yang terdiri dari pendidikan, usia, beban anggungan dan pendapatan serta lama bekerja berkerja 
sebagai pembantu. Variabel lainnya meliputi alasan bekerja sebagai pembantu, pendapatan dan jam kerja serta sumbangan kerja bagi keluarga. Metode analisis menggunakan tabulasi silang (cross-tabulation) dan distribusi frekuensi.

\section{Hasil Penelitian dan Pembahasan}

Dilihat dari tingkat pendidikan Pekerja Rumah Tangga(PRT), rata-rata menunjukkan tingkat pendidikan yang tergolong rendah. Di mana sebagian PRT masuk dalamkategori pendidikan rendah yaitu dari 51 responden $92,2 \%$ hanya dapat memperoleh pendidikan SMP ke bawah. Ini menunjukkan tingkat produktivitas mereka rendah, mereka umumnya bekerja hanya mengandalkan fisik mereka yang masih mampu untuk bekerja pada usia-usia produktif. Kondisi ini menggambarkan bahwa pekerjaan yang sesuai dengan kondisi pendidikan PRT hanyalah sebagaipelayan (pembantu rumah tangga) yang sesungguhnya dalammenjalankan pekerjaannya tidak memerlukan spesifikasi keilmuan khusus, hanya dibutuhkan pengalaman, kesabaran, dan fisik yang sangat mendukung. Dari 51 responden 47,1\% memiliki pendidikan SD, 37,3\% memilki pendidikan SMP, dan hanya $7,8 \%$ saja yang merasakan pendidikan tingkat atas (SMA).

Dilihat dari usia pekerja rumah tangga umumnya memiliki usia produktif (masuk pada usia tua), di mana $27,4 \%$ memiliki usia 36 - 40 tahun, dan $31,4 \%$ masuk pada usia tua (41 - 45 tahun). Dengan semakin tua usia dan lamanya mereka bekerja sebagai PRT menunjukkan pengalaman dan produktivitas kerja pada sektor jasa tersebut. Dengan demikian usia dan lamanya mereka bekerja pada pekerjaan PRT dapat berdampak pada perubahan kualitas mereka bekerja serta menjadikan mereka memiliki ba- nyak pengalaman serta adanya kedekatan antara majikan dengan pekerja (patron-klien). Semakin tinggi usia dari PRT menunjukkan lamanya dia bekerja sebagai PRT. Pada usia 36 - 40 tahun yang lama bekerja di atas 6 tahun sebagai PRT adalah sebesar $57,1 \%$ dan sisanya $14,3 \%$ di bawah 5 tahun. Demikian juga juga pada interval usia 41-45 tahun 43,7\% juga bekerja sebagai PRT selama 6 tahun, dan $25 \%$ antara $4-5$ tahun. Pada usia 46 - 50 tahun menunjukkan suatu pengalaman bekerja sebagai PRT cukup lama yaitu sekitar 66,7\%. Dengan perkataan lain bahwa pada usia 36 - 50 tahun, PRT akan semakin produktifdan banyak pengalaman yang mereka miliki. Hal ini dikarenakan pola kerja yang dilakukan oleh mereka sangat disenangi dan cocok bagi ibu rumah tangga yang menggunakan jasa mereka. Tatacara, kesopanan, kebersihan, danjadwal kewajiban yang harus mereka lakukan. Dibandingkan mereka yang masih tergolong usia muda (remaja) bahkan yang belum berkeluarga.

Beban tanggungan (dependency ratio) adalah merupakan angka beban kehidupan ekonomi yang ditanggung oleh keluarga PRT. Beban tanggungan tersebut meliputi jumlah anak dan saudara yang menjadi tanggung jawab secara ekonomi. Faktor ini dapat juga sebagai penentu ibu rumah tangga di pedesaan untuk memutuskan bekerja sebagai PRT. Bila dilihat dari jumlah tanggungan keluarga yang miliki oleh PRT yang bekerja di kecamatan Dau, sebagian besar memiliki bebantanggungandiatas 3 orang. Jumlahtanggungan yang menjadi tanggung jawab PRT, di mana 39,2\% memiliki tanggungan sebanyak 2 -3 orang, dan 31,4\% sebanyak 4-5 orang, sedangkan mereka yang memiliki beban tanggungan keluarga diatas 6 orang sebanyak $9,8 \%$, umumnya yang menjadi tanggungan PRT adalah anak, adik, keponakan baik dari saudara suami atau istri. 
Kontribusi Wanita dalam Aktivitas Ekonomi dan Rumah Tangga... (Dwi E. W., Uci Y.)

Berdasarkan pada pembahasan sebelumnya, dapat dijelaskan bahwa faktor-faktor seperti tingkat pendidikan, usia, beban tanggungan keluarga, dan pendapatan suami merupakan faktor pendorong dari ibu rumah tangga untuk bekerja sebagai PRT, dan juga sebagai pendorong PRT untuk berupaya mengejar pendapatan yang mereka peroleh. Upaya mengejar pendapatan tersebut identik dengan kemampuanjumlahjamkerja yang mereka lakukan dengan berupaya meningkatkan keterampilan diri agar dapat diperhatikan oleh majikannya.

Gambar 1 dapat kita lihat bahwa ratarata jam kerja yang dimiliki oleh ibu rumah tangga yang bekerja sebagai PRT yaitu di atas 7 jam kerja setiap harinya. Hal ini sangat menarik untuk dikaji lebih jauh antara lain bagaimana mereka mengatur waktu di rumah (sebagai ibu rumah tangga) dengan pekerjaannya sebagai PRT. Dari data tersebut dapat dijelaskan bahwa 37,3\% ibu rumah tangga memberikan waktunya untuk bekerja sebagai PRT antara 7 s/d 8 jam perhari, dan 27,4\% dari responden (PRT) yang memberikan waktunya di luar rumah tangga mereka di atas 11 jam per hari.

Pada umumnya para pekerja pembantu rumah tangga yang bekerja kurang dari
4-6 jam perhari, adalah mereka yang bekerja hanya setengah hari. Dalam arti pekerjaan yang mereka lakukan adalah hanya membersihkan rumah, mencuci dan menyetrika. Sedangkan mereka yang bekerja 7 - 10 jam per hari, aktifitas pekerjaannya berbeda dengan mereka yang memiliki waktu kerja di bawah 6 jam perhari. Pekerjaan yang mereka lakukan adalah membersihkan rumah, memasak, mencuci dan menyetrika serta menjaga anak. Waktu yang mereka lakukan adalah mulai jam 7 atau jam 8 berangkat dan pulang pada jam 4 atau 5 sore. Kemudian kondisi tersebut juga sangat berbeda dengan mereka yang memiliki waktu kerja di atas 11 jam/ hari, aktifitas yang mereka lakukan adalah sesuai dengan aktifitas ibu rumah tangga yaitu mulai ke pasar sampaai pada aktifitas lain yang dibutuhkan oleh majikannya baik yang sifatnya rutinitas maupun sewaktu-waktu tanpa adanya planning. Umumnya mereka yang bekerja di atas 11 jam per hari tersebut adalah mereka yang tinggal dengan majikannya, artinya mereka memilikikesempatan pulang biasanya adalah satu minggu sekali, satu bulan sekali, dan bahkan pulang tergantung dari keinginan pembantu itu sendiri.

Usia merupakan salah satu faktor yang dapat diduga memiliki hubungan yang kuat

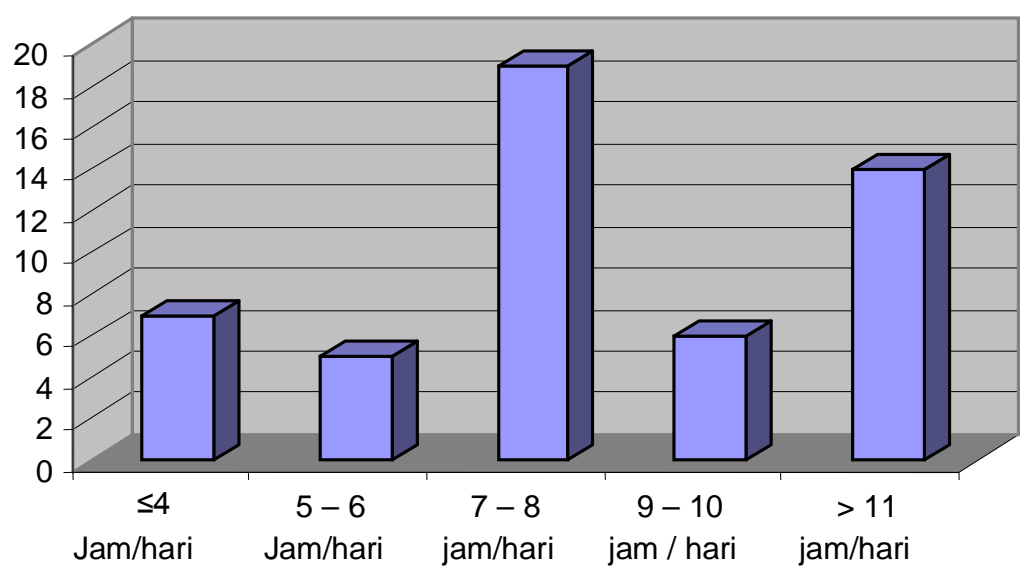

Gambar 1. Jumlah Jam Kerja 
dalam menentukan jam kerja yang dimiliki oleh PRT. Umumnya seorang majikan menggunakan jasa PRT adalah mereka yang sudah berstatus ibu rumah tangga. Hal ini dikarenakan komitmen kerja yang dmiliki oleh mereka yang berkeluarga sangat berbeda dengan mereka yang belum berkeluarga. Pengaruh negatif cukup tinggi bagi PRT yang belum berkeluarga. Kenyataan menunjukkan adanya pengaruh lingkungan (sisi penampilan), perbedaan upah, kurangnya tanggung jawab. Sedangkan bagi PRT yang sudah berkeluarga sangat memiliki tanggung jawab yang kuat terhadap pekerjaan dan beban yang harus dilaksanakan.

Untuk usia di atas 50 tahun, jam kerja yang diinginkan oleh PRT terus mengalami tambahan jamkerja seiring dengan lamanya dia bekerja sebagai PRT, akan tetapi kondisi fisik mereka justru yang harus diperhatikan. Dengan demikian aktifitas kegiatan yang dilakukan akan semakin berkurang seiring dengan bertambahnya usia PRT. Umumnya mereka yang bekerja di atas $12 \mathrm{jam} / \mathrm{hari}$ adalah mereka yang tinggal dengan majikan dan kembali melihat rumah tangga mereka setelah bekerja satu minggu, satu bulan, bahkan berbulan-bulan.

Pada umumnya ibu rumah tangga yang bekerja memiliki beberapa tujuan utama bagi kehidupan ekonomi keluarga, yang kesemuanya adalah merupakan faktor pendorong utama bagi mereka yang berupaya untuk memberikan waktunyaantara rumahtangga dan tempat kerja. Bagi wanita pedesaan atau pinggiran kota yang tidak mempunyai pekerjaan, tujuan utama dalam memilih peluang kerja adalah sebagai pembantu rumah

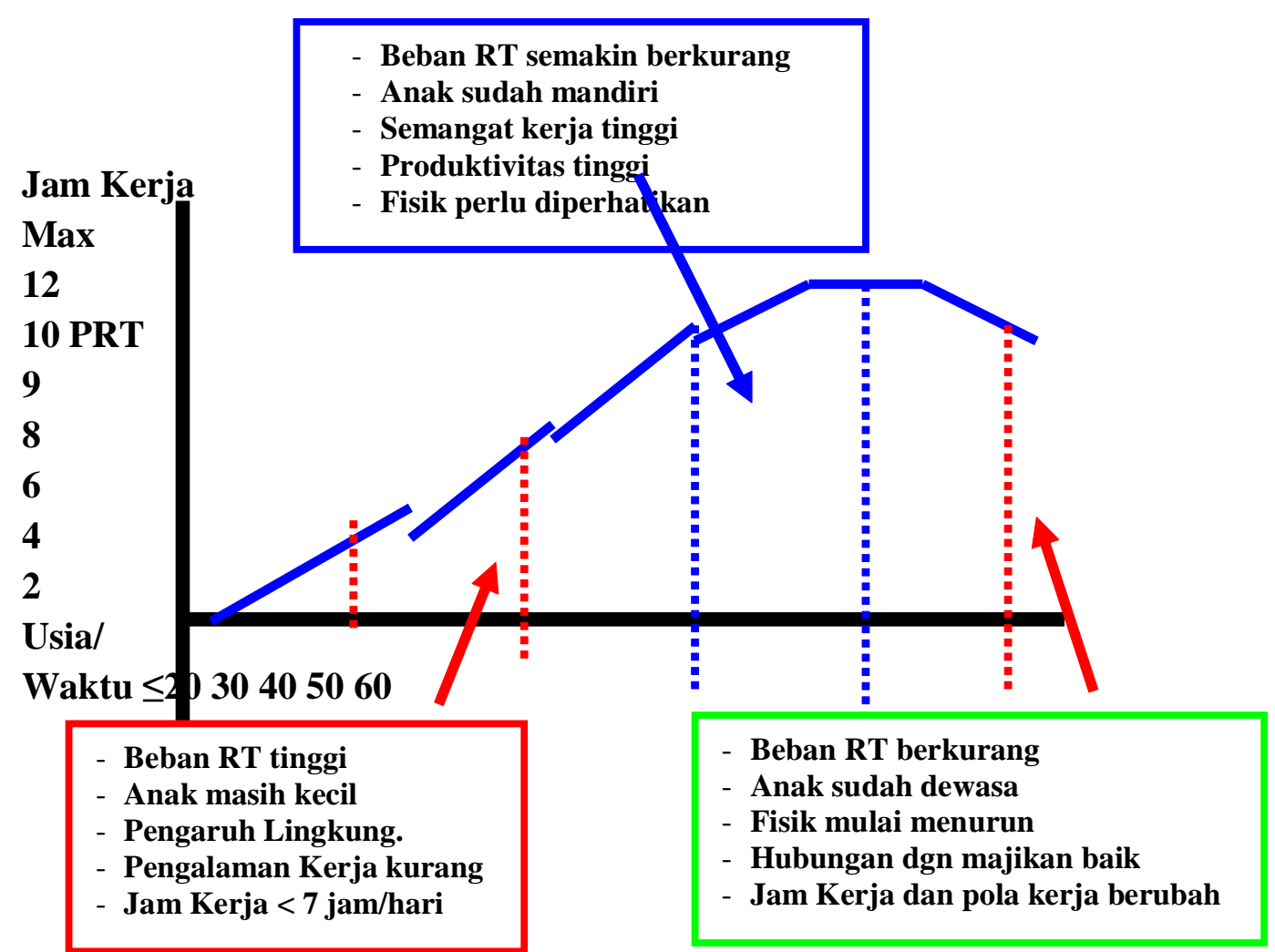

Gambar 2. Produktivitas Kerja dan Pola Pembagian Kerja PRT 
tangga (PRT). Dipilihnya PRT karena pekerjaan ini tidak memiliki persyaratan keterampilan khusus dan tingkat pendidikan utama, yang terpenting adalah ketelatenan, keramahan, dan keluwesan dalam bertindak untuk keperluan kegiatan rutin dalam rumah tangga. Selanjutnya dorongan untuk bekerja sebagai PRT sangatlah bervariasi, dan beberapa alasan mereka bekerja sebagai PRT adalah sebagai berikut: (1) Membantu ekonomi keluarga. (2) Mencukupi kebutuhan ekonomi keluarga. (3) Bantu suami mencarinafkah. (4) Menambah penghasilan rumah tangga. (5) Biaya menyekolahkan anak. (6) Nyaman dibanding bekerja sebagai buruh tani.

Berdasarkan alasan di atas, yang paling banyak ditemui adalah karena dampak dari ekonomi rumah tangga yang serba kekurangan. Kondisi inilah yang menjadikan ibu rumah tangga memiliki niat yang kuat dengan didorong oleh suami untuk bekerja pada sektor jasa rumah tangga yaitu sebagai PRT di wilayah kecamatan Dau.

Bila dilihat dari kontribusi pendapatan PRT terhadap ekonomi rumah tangga juga sangatlah bervariasi. Pada 51 responden ada yang mengatakan bahwa pendapatan sangat membantu, cukup membantu, bahkan ada juga yang mengatakan masih belum mencukupi dalam pemenuhan kebutuhan hidup rumah tangganya dapat dilihat pada gambar 3 .

Berdasarkan pada hasil tanggapan dari responden dapat dikatakan bahwa 41,2\% menyatakan pendapatan yang diterima sudah memenuhi harapan ekonomi keluarga, 33,3\% mengatakan masih belum memenuhi harapan yang diinginkan oleh keluarga dalammemperbaiki ekonomi rumah tangga, dan 25,2\% mengatakan sudah cukup untuk memenuhi kebutuhan ekonomi rumah tangga. Umumnya mereka yang mengatakan bahwa dari hasil bekerja sebagai pembantu rumah tangga yang memiliki pendapatan di atas Rp.350.000 per bulan serta bekerja di atas 8 jam kerja per hari.

\section{Penutup}

Kondisi kehidupan pekerja pembantu rumah tangga (PRT) memiliki berbagai fenomena yang sangat menarik, terutama dalam hal pola kehidupan dan sistempembagian kerja antara rumah tangga dengan pekerjaannya sebagai PRT Berdasarkan pembahasan dapat diambil beberapa kesimpulan sebagai berikut: Pertama, karakteristik sosial ekonomi yaitu dilihat dari tingkat pendidikan,

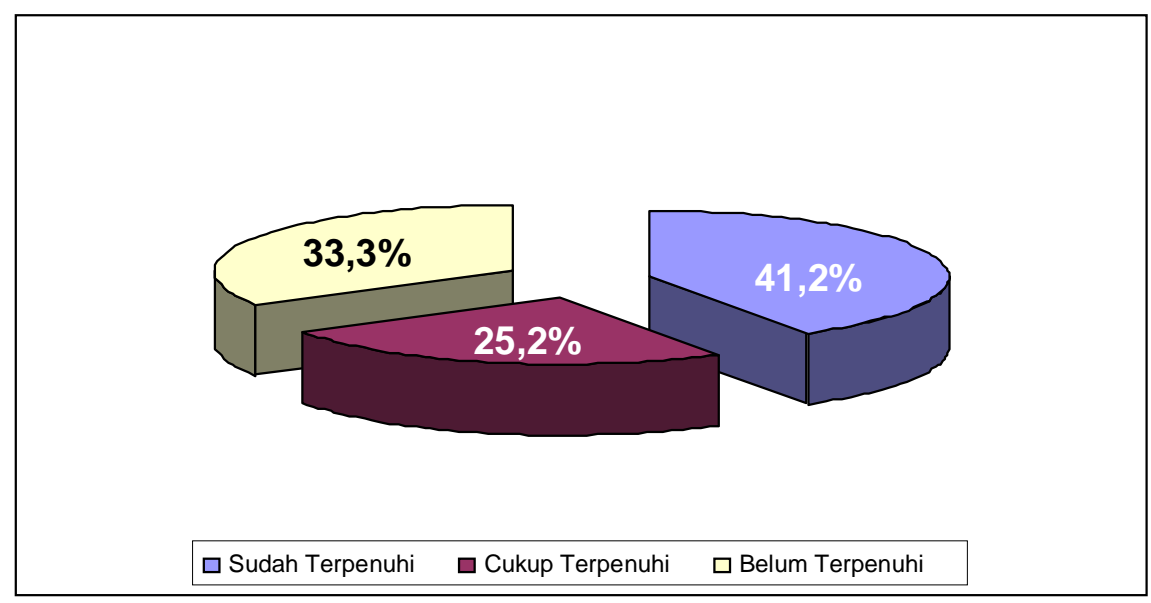

Sumber: data primer diolah

Gambar 3. Respon PRT Tentang Penghasilan 
usia, beban tanggungan PRT, dan jenis pekerjaan suami, dapat dikatakan bahwa tingkat pendidikan pekerja rumah tangga umumnya masuk dalam kategori pendidikan rendah yaitu 92,2\% hanya dapat memperoleh pendidikan SMP kebawah. Kondisi ini menggambarkan bahwa pekerjaan yang sesuai pendidikan PRT hanyalah sebagai pelayan (pembantu rumah tangga) yang sesungguhnya dalam menjalankan pekerjaannya tidak memerlukan spesifikasi keilmuan khusus, hanya dibutuhkan pengalaman, kesabaran, dan fisik yang sangat mendukung. Pendidikan pembantu sebesar $47,1 \%$ adalah Sekolah Dasar, $37,3 \%$ adalah SMP, dan hanya $7,8 \%$ saja yang merasakan pendidikan tingkat atas (SMA). Berdasarkan usia pekerja rumah tangga umumnya mereka berusia produktif (masuk pada usia tua), di mana 27,4\% memiliki usia 36 - 40 tahun, dan 31,4\% masuk pada usia tua ( $41-45$ tahun). Semakin tua usia dan semakin lama bekerja sebagai PRT menunjukkan tingkat pengalaman dan produktivitas kerja pada sektor jasa tersebut. Dengan demikian usia dan lamanya mereka bekerja pada pekerjaan PRT dapat berdampak pada perubahan kualitas mereka bekerja serta menjadikan mereka memiliki banyak pengalaman serta adanya kedekatan antara majikan dengan pekerja (patron-klien). Dilihat darijumlah tanggungan keluarga yang miliki oleh PRT yang bekerja di kecamatan DAU, sebagian besar berjumlah di atas 3 orang. Jumlah tanggungan yang menjadi tanggung jawab PRT, 39,2\% memiliki tanggungan sebanyak 2 -3 orang, dan 31,4\% sebanyak $4-5$ orang, sedangkan mereka yang memiliki beban tanggungan keluarga diatas 6 orang sebesar $9,8 \%$, umumnya yang menjadi tanggungan PRT adalah anak, adik, keponakan baik dari saudara suami atau istri.
Kedua, beberapa alasan wanita bekerja sebagai pembantu rumah tangga adalah membantu ekonomi keluarga, mencukupi kebutuhan ekonomi keluarga, membantu suami mencari nafkah, menambah penghasilan rumah tangga, biaya menyekolahkan anak dan perasaan nyaman sebagai pembantu rumah tangga dibandingkan bekerja sebagai buruh tani.

Ketiga, alokasi waktu pembantu bekerja sebagai pembantu rumah tangga ratarata 8 jam per hari bagi mereka yang tidak tinggal di rumah majikan dan 11 jam per hari bagi mereka yang tinggal bersama keluarga majikan dan pulang seminggu sekali atau sebulan sekali.

Keempat, kontribusi pendapatan wanita sebagai pembantu rumah tangga adalah banyaknya pendapatan yang diperoleh yang dapat digunakan untuk memenuhi kebutuhan keluarganya. Rata pendapatan yang diperoleh adalah Rp. 350.000,- dengan jam kerja 8 jam per hari. Dengan pendapatan sebesar itu ternyata $41,2 \%$ menyatakan sudah memenuhi harapan ekonomi keluarga, 33,3\% mengatakan masih belum memenuhi harapan yang diinginkan oleh keluarga dalammemperbaiki ekonomirumah tangga, dan 25,2\% mengatakan sudah cukup memenuhi kebutuhan ekonomi rumah tangga.

\section{DAFTAR PUSTAKA}

Aryani, Ni. Luh. 1991. Pekerja Wanita Pada Industri Rumah Tangga Sandang Di Propinsi Bali. Pusat Penelitian Kependudukan UGM. Yogyakarta.

Ashari, S. 1986. Industri Kecil Sebuah Tinjauan dan Perbandingan. LP3ES. Jakarta. 
Kontribusi Wanita dalam Aktivitas Ekonomi dan Rumah Tangga... (Dwi E. W., Uci Y.)

Hastuti, E.L. 1998. Studi Peranan Wanita Dalam Pengembangan Usaha Pertanian Spesifik Lokasi. P/SE. Badan Litbang Pertanian, Departemen Pertanian. Jakarta.

Hastuti, E.L. 2004. Pemberdayaan Petani dan kelembagaan Lokal Dalam Perspektif Gender. working paper. Pusat Penelitian dan Pengembangan SosialEkonomi Pertanian.

Hastuti. E.L. 2004. Hambatan Sosial Budaya Dalam Pengarustamaan Gender Di Indonesia. Pusat Penelitian Dan Pengembangan Sosial Ekonomi Pertanian, Departemen Pertanian. Jakarta.

Kuncoro, Mudrajat. 2003. Metode Riset Untuk Bisnis Dan Ekonomi. Airlangga. Jakarta.

Mc. Cawly. 1979. Industrialisation In Indonesia. ANU. Canberra.

Muryani. 1985. Potensi Buruh Wanita Di Sektor Industri dan kontribusinya Terhadap Pendapatan Keluarga, Tesis S2 Kependudukan, Fakultas Pasca Sarjana. UGM. Yogyakarta.

Nursyahbani, Kacangsukana. 1999. Perempuan Dalam Peta Hukum Negara Indonesia; dalam Buku Menakar Hatga Perempuan. Mizan. Bandung.

Sajogyo. 1983. Peranan Wanita Dalam Perkembangan Masyarakat Desa. Rajawali. Jakarta.

Sekaran, U. 2000. Research Methods for Business: A Skill Buillding Aproach, (3rd ed). John Wiley \& Sons, Inc. New York.

Seomartoyo, S.R. 2002. Pemberdayaan
Perempuan di Indonesia dan Peluang Untuk Pemberdayaan Ekonomi Perempuan. Disampaikan Oleh Mentri Pemberdayaan Perempuan Pada The ACT Seminar and Summit., Japan-Indonesia: Dinamic Relationship for Regional Development.

Siswidiyanto, dkk. 1998. Pekerja Wanita Pada Industri Rumah Tangga Sandang dan kontribusinya Terhadap Pendapatan Rumah Tangga di Kec. Tulungagung Kab. DatiII Tulungagung. Jurnal Penelitian Ilmu-ilmu Sosial. Vol.10 No. 2, Unibraw, Malang.

Sumiati, S. 2000. Wanita dan Sektor Informal: Peran dan Kedudukannya Dalam Rumah Tangga (studi kasus penjual sayur dan jamu gendong di kota Malang). Jurnal Ilmu-ilmu Sosial. Vol. 12 No. 2 tahun 2000., Unibraw, Malang.

2004. Studi dan Kajian Potensi Sarana Perekonomian Kota Batu. Sekretariat Daerah Kota Batu-LPEM Fakultas EkonomiUniversitas Brwijaya Malang. 
